\title{
OTA's stormy ride
}

\section{Colin Norman in Washington examines the history and prospects of the Office of Technology Assessment}

lacked the resources to match the technical expertise of the executive branch on such complex matters. At that time Daddario was a Congressman from Connecticut and he held a key position as chairman of the science subcommittee of the former Committee on Science and Astronautics.

After holding a number of hearings with his subcommittee in the late 1960s, Daddario sponsored legislation to create an agency of the Congress to assist in the evaluation of technological matters and to provide an early warning system to pinpoint potential side effects and long term implications of projects and policies involving science and technology. Congress finally passed a bill establishing OTA in October 1972, though by that time Daddario had left Congress to run (unsuccessfully) for the governorship of Connecticut. Kennedy played a leading role in shepherding the bill through the Senate.

The bill specified that OTA would be run by a 13-member board, consisting of 6 Senators, 6 members of the House and the director of OTA. Republicans and Democrats would be equally represented on the board. In addition, the legislation established an independent advisory committee to provide policy advice to the board.

The legislation also specified that the chairmanship of the board should alternate every two years between Senators and House members. Kennedy was elected the first chairman. $\mathrm{He}$ was followed by Olin Teague, chairman of the House Committee on Science and Technology, who served during 1975 and 1976, and Kennedy resumed the chairmanship earlier this year. Daddario, meanwhile, was appointed director in 1973 for a six-year term.

OTA represented a major innovation in the Congressional process. It was designed to provide Congress with long-range analysis, act as a counterweight to the technological expertise of the executive branch, and function as an early warning system. It is very much a creature of the Congress, having to respond to the concerns of legislators and provide analyses of issues on a timescale which can effect the passage of particular bills. One OTA staff member last week likened OTA's establishment to an organ transplant: "We grafted it into Congress and waited to see if it would take", he said.

The graft took slowly, and there

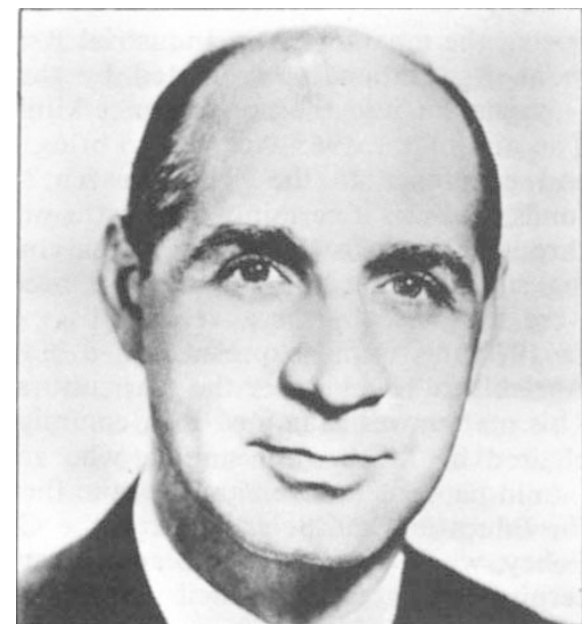

Daddario: just changing jobs?

have been occasional signs of rejection. First, it took a long time to get the initial studies under way because Congress was slow in appropriating money for OTA. There were also a number of internal problems in securing office space and assembling staff. But OTA began to crank out a huge volume of material. Some 46 studies have now been completed, and 34 more are in the works. Topics have ranged over a broad spectrum, including the bioequivalency of supposedly identical prescription drugs, policies to curb nuclear proliferation, the potential for small scale solar technology (see page 6), and a broad assessment of the impacts of offshore oil and gas production. OTA has also produced a number of critiques of specific administration policies, such as energy plans published by the Energy Research and Development Adminstration (ERDA), President Carter's energy policy, and the research and development strategy of the Environmental Protection Agency.

Though arrangements differ from one study to another, the general procedure is to establish an advisory committee of outside experts to help plan and monitor each project. The advisory panels are usually deliberately chosen to reflect diverse points of view, frequently containing members of public interest groups and businessmen. The studies themselves are usually carried out by OTA staff, sometimes with the help of outside contractors, under the guidance of the advisory panels and with overall management provided by a programme director.

\section{Important criticisms}

But OTA has run into a number of important criticisms during its short lifetime, and there have been occasional signs that Congress may reject this strange transplant. The grumbles have, however, concerned OTA's style of operation rather than the quality of its reports and analyses. 
The first complaints came from OTA's advisory council, which grumbled that it was not being sufficiently consulted on matters of policy. Then, in June last year, the House Commission on Information and Facilities, an obscure Congressional unit headed by Representative Jack Brooks, charged that OTA's internal management was in a mess and that there was general confusion about the agency's mission. That blast was followed by criticism from Harold Brown, now Carter's Secretary of Defense, who resigned last July as chairman of OTA's advisory council and claimed in his letter of resignation that the office had become bogged down in responding to requests for relatively trivial policy studies to the detriment of its primary mission of providing an early warning system. Then last October, a House/Senate conference committee recommended that OTA's budget should be cut and suggested that the fledgling agency had yet to prove its worth to Congress. Finally, from outside OTA have come sporadic complaints that the office has been too cautious in its approach and that it has not really been performing technology assessment.

Asked to comment on some of those criticisms in an interview with Nature before he left office, Daddario acknowledged that, "Sure we have had our problems, but every institution in this town has had its problems". $\mathrm{He}$ pointed out that most of the criticism was directed at bureaucratic arrangements when OTA was still feeling its way and evolving its style of operation. It has taken three years to develop a sound process to handle the studies, Daddario said, and suggested that it could take at least a decade before the office is functioning smoothly with the full support of the Congress. Daddario noted that none of the criticism has been directed toward the quality or credibility of OTA's studies and it is that, after all, which will ultimately

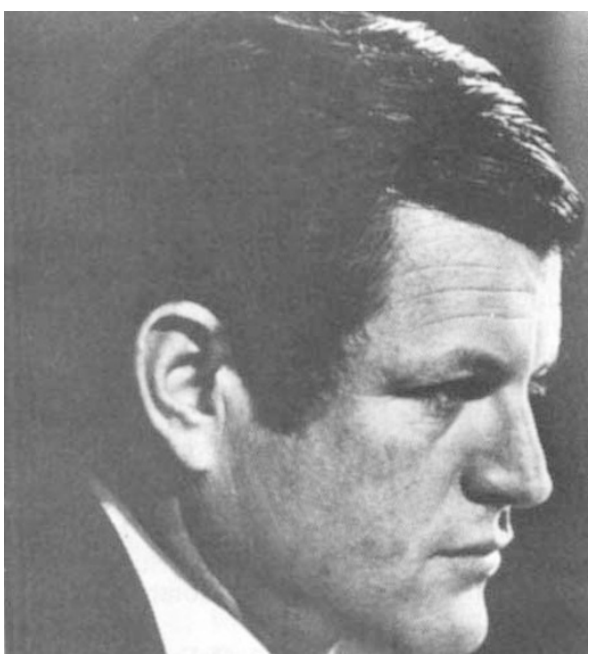

Kennedy: how much influence? determine the office's influence.

It is indeed possible to point to a number of OTA analyses which had an impact on policy. The critiques of energy policy, for example, suggested that ERDA was paying too little attention to conservation, and the policy was subsequently changed. ERDA Administrator Robert Seamans acknowledged in a press conference early last year that OTA's analyses had played a significant role in shifting funds into conservation programmes in ERDA. The study on offshore oil and gas production has attracted attention and is praised for raising public awareness of many of the central issues involved in the Administration's plans. The drug bioequivalence study, which was the first published by OTA, played a major role in shaping federal policy for drug purchasing under government-financed health care schemes.

Though OTA staffers are quick to note such examples of the office's influence, there has so far been no coherent review of the quality of OTA's reports or the use to which they are put. Two such studies are, however, being planned. The first will be conducted this autumn by the House Committee on Science and Techno$\log y$, and the second will be carried out by OTA's own advisory council. The latter study was initiated earlier this year by OTA's Congressional board, largely at the urging of Senator Kennedy. And that brings us back to the latest round of political upheavals at OTA.

\section{Kennedy allegations}

Allegations that Kennedy planned to take control of OTA were raised when the office was first established and Kennedy was elected chairman of its board. An article in the Wall Street Journal in 1973, for example, charged that Kennedy would use OTA as the springboard for his 1974 Presidential election campaign, and in the same vein Safire's recent column in the New York Times suggested that Kennedy has little influence on the Carter Administration so he is quietly taking control of OTA to build up his own power base.

Few people deny that Kennedy has a strong influence on OTA affairs. His supporters claim, however, that his influence derives from the fact that he is the most active and interested member of the board. His detractors claim that his influence derives from the fact that some of his own staff members work for OTA and that the chairman of OTA's advisory council, Jerome Weisner, is an old political ally of Kennedy's. It should be noted, however, that Kennedy is not alone in having his own staff working for OTA.
Other Senate members of the board have at least one staff liaison with OTA, a fact which has drawn criticism from some other OTA staffers because the political appointees have divided loyalties.

Mrs Holt told Nature last week that she resigned from the board because she felt that it "was obvious that we were having no opportunity to make any input at all". On three recent issues Holt was outvoted on the board by Kennedy and his supporters. In each case, she was supported by Teague and the other two House Republicans. The first issue arose when the board refused to reappoint a Texas Instruments executive, Fred Bucy, to a second term on the advisory council. Kennedy opposed the reappointment because Bucy had attended too few meetings in his first term; Holt claimed that Kennedy simply didn't like Bucy's stand on some issues. Second, the board sanctioned a quick assessment of the data which led to the proposed ban on saccharin over Holt's objection that such a study wouldn't add anything to the debate. And third, Holt unsuccessfully resisted a move to have the advisory council conduct a study of OTA's operations.

Underlying the dispute is a significant political gulf between Holt, a conservative Republican, and Kennedy, a prominent liberal Democrat. OTA, in short, has become a battleground for partisan politics.

As for Safire's allegation that Kennedy had engineered Daddario's resignation to pave the way for installing his own candidate in the director's chair, Daddario insisted that his resignation stemmed from nothing more than a desire to change jobs. He said that he had originally planned to stay for only three years but stayed longer to see the solar study and the critique of Carter's energy policy through.

Whether or not these upheavals will leave lasting scars depends largely on who is chosen to succeed Daddario. Kennedy is taking scrupulous care to avoid suspicion that he is trying to influence the selection process. He has asked for nominations from scores of organisations, the advisory council will screen the candidates and the board will make the final selection. So far, the only announced candidate is Daniel V. Desimone, who has been deputy director for the past three and a half years. Ellis Mottur, who now heads a major OTA programme, has been nominated by several groups, but he told Nature that he has asked the council not to consider him because his close ties with Kennedy would be sure to encourage Kennedy's opponents.

The next few months are clearly going to be critical for OTA. 